\title{
Navigating the Ripple Effects: Brazil-China Relations in Light of the Belt and Road Initiative (BRI)
}

\author{
A. E. Abdenur \\ International Peace and Security division of Igarapé Institute, \\ 64, Rua Miranda Valverde, 22281-000, Rio de Janeiro, Brasil
}

For citation: Abdenur A. E. Navigating the Ripple Effects: Brazil-China Relations in Light of the Belt and Road Initiative (BRI). Vestnik of Saint Petersburg University. International Relations, 2019, vol. 12, issue 2, pp. 153-168. https://doi.org/10.21638/11701/spbu06.2019.203

The literature on Brazil-China relations has expanded rapidly during the past decade, but most of this scholarship has focused on bilateral channels or on the broad trends in how China's growing presence impacts politics, economics, and society in Brazil. Largely left out of this equation is how China's cooperation and competition dynamics within its own region shape its relations to Brazil. How does the promotion of the Belt and Road Initiative (BRI) affect Brazil's relations with China? This paper draws on official documents and statistics to analyze how the BRI affects Brazil's relations with China along three dimensions: the economic, strategic, and political spheres. I argue that, despite the geographic distances separating Brazil from the Belt and Road Initiative, the initiative has concrete repercussions for Brazil's bilateral and multilateral dealings with China through a ripple effect emerging out of the BRI's spatial configuration. The paper also proposes that most of this impact is shaped by a ripple effect emerging out of the BRI's spatial configuration, although some components of the initiative, namely the Digital Belt and Road, are less anchored in geographic space. Brazilian researchers and policymakers must think beyond bilateral channels and consider how geopolitics and geoeconomics shape Brazil-China relations.

Keywords: Brazil, China, Belt and Road, South-South cooperation.

\section{Introduction}

The literature on Brazil-China relations has expanded rapidly during the past decade, but most of this scholarship has focused on bilateral channels or on the broad trends in how China's growing presence impacts politics, economics, and society in Brazil [1]. Another strand of the literature considers the growing influence of China in Brazil and, more broadly, on Latin America and the Caribbean, especially in light of intensifying geopolitical competition with the United States - although analyses of Latin America's impact on China are still scarce. Left out of this equation is how China's cooperation and competition dynamics within its own region shape its relations with Brazil. This paper pulls back from the bialteral lens typically cast on Brazil-China relations to consider how these ties are shaped by broader changes at the regional level, focusing on the emerging space I refer to as Greater Eurasia. More specifically, how does the promotion of the China-centered Belt and Road Initiative (BRI) affect Brazil's relations with China?

This paper draws on official documents and statistics to analyze how the BRI affects Brazil's relations with China along three dimensions: the economic, strategic, and

(c) Санкт-Петербургский государственный университет, 2019 
political spheres. I argue that, despite the geographic distances separating Brazil from the BRI, the initiative has concrete repercussions for Brazil's bilateral and multilateral dealings with China. Most of this impact is shaped by a ripple effect emerging out of the BRI's spatial configuration, although some components of the initiative, namely the Digital Belt and Road, are less anchored in georgraphic space. Brazilian researchers and policymakers must think beyond bilateral channels and consider how geopolitics and geoeconomics shape these two states' dynamic ties as actors embedded within a world order. While navigating the ripple effects of the BRI, Brazil will also have to make decisions about whether, and to what extent, it wishes to join the initiative.

The paper is structured in three parts. The first section provides an overview of the literature on the BRI within the context of the multipolarization of the world order, and it offers some background on Brazil-China relations. The second section analyzes the ramifications of the BRI for Brazil across different sectors: economic, strategic / defense, and political. The conclusion considers the broader implications of the BRI for Brazil's position in the changing world order and notes some directions for future research.

\section{The Belt and Road Initiative and Latin America}

\section{a) Multipolarization of the world order and the BRI}

Although the exact nature of the structural transformation underway in the world order remains the subject of sharp debate among scholars of international relations, there is broad agreement among scholars that the system that emerged in the post-Cold War period has changed dramatically in the past ten years. Realists stress the shifting balance of power at a global level and call attention to new patterns of conflict and competition [2], while liberals note the proliferation of new cooperation arrangements (especially among non-democracies) and the crisis in multilateralism that has beset traditional institutions such as the UN and the Bretton Woods organizations. Constructivists see a world of change in which perceptions and understandings of power and their associated social ties are changing, as reflected in major shifts in discourse, for instance by intellectual entrepreneurs and networks that attempt to distance themselves from Western-centric language, concepts, and principles. The expansion in usage of expressions such as SouthSouth cooperation, win-win or mutual benefit, solidarity and horizontality point to the spread of cooperation norms that are not entirely aligned with the principles promoted by key Western-led institutions, such as the Organisation for Economic Cooperation and Development (OECD).

In addition, many analysts believe that this overarching change in the world order, however uncertain in character and destination, has been accelerating in the 2010s [3-5]. After a period of contested US hegemony, the world has seen new poles of economic growth and political contestation arise. Whether from individual rising powers or loose coalitions of states such as the BRICS, some of the institutions and norms established in the Post-World War II period began to experience heightened contestation and, in some cases, additional competition from parallel institutions, as in the case of the BRICS New Development Bank (NDB), the Contingengy Reserve Arrangement (CRA) and Asian Infrastructure Investment Bank (AIIB). These new institutions reflect changing alignments, as well as new forms of geopolitical and geoeconomic competition. As Robert Wade [5] 
has put it, the world economy has shifted from "unipolar" toward "multipolar", less clearly dominated by the G7 - but this change has been uneven, varying widely across different spheres of international relations. The G20's role in global economic governance, for instance, has become highly uncertain, even fragile, especially when compared to the period of effervescence among rising powers in the 2010s.

The most prominent of the emergent hubs of economic and, by extension, political power lies in Asia, and more specifically is anchored in the remarkable resurgence of China as a global power. The shift in the global center of gravity towards Beijing has been propelled not only by China's growing economy, which experienced nearly two decades of double-digit growth, but also by the expanding reach of its strategic ties. China began investing heavily abroad starting in the 1990s with its "Go Out" policy, designed to find new niches and markets for the country's rapidly expanding surplus of capital. Cooperation ties promoted under the banner of South-South win-win relationships expanded rapidly across the developing world, especially in Asia and Africa and centered on the financing of large-scale infrastructure. At the same time, incremental changes to China's defense policy, especially its maritime dimension, demonstrated Beijing's increasing concern with security issues beyond the country's immediate neighborhood, while the People's Liberation Army Navy (PLAN) extended and improved its capabilities both regionally and extra-regionally. These changes have provoked new tensions, especially among strategic circles in the West (primarily in the United States, which stands to lose its maritime stronghold in the Pacific) and in other neighboring countries such as some of China's Pacific neighbors and India.

Even with the slowdown of the Chinese economy, China's rise means that the structural changes that the world order is undergoing are deeply asymmetrical. The BRICS, promoted as a coalition of rising powers, has become decidedly lopsided as a result of China's growing strength and, on the other hand, the "submergence" of Brazil and South Africa in particular (both of which grapple with political turbulence and economic crisis). Nevertheless, the re-emergence of China is not co-terminous with multipolarization. Even within its own region, China has continued to face contestation and rivalry with a number of neighboring and proximate states, from Japan to India, even as they seek to expand cooperation ties with Beijing, especially along economic lines. Ambiguity has also marked China's relations with Russia, but the two countries have overcome some significant points of mutual distrust and ties have deepened significantly in the 2010s, not only bilaterally but also via the Shanghai Cooperation Organization (SCO), leading to the deepest approximation between Beijing and Moscow since the Sino-Soviet Alliance of the 1950s. The ability to sustain this momentum is one crucial element in the implementation of the BRI and the consolidation of Greater Eurasia within the world order.

By the mid-2010s, China began seeking new ways to channel its economic leverage and expand political influence abroad. This ambition was partly driven by President Xi Jinping's quest to avoid a "hard landing" and to structurally transform the Chinese economy, namely by increasing the weight of domestic consumption and increasing the country's capacity to innovate and produce higher value-added goods. Alongside this ambition are growing concerns with food, water, and energy security, for which China has worked to implement solutions domestically but also to expand cooperation ties abroad that enable the Chinese government to assure the supply of these basic services, whose disruption could constitute an existential threat to the Chinese Communist Party [6]. 
Seeking new spaces abroad became one way that Chinese actors could propel these domestic changes while consolidating a zone of Chinese influence in the emerging Greater Eurasia. In other words, economic interests dovetailed with geopolitical interests, and even security ones.

The idea of "reviving" the ancient Silk Road by consolidating a double corridor, one part land-based and the other maritime, across the Eurasian space was first made public by President Xi Jinping in 2013, when he used a speech to envision a $21^{\text {st }}$ century maritime Silk Road. As of 2018, the initiative, renamed Belt and Road, focused on two corridors: the Silk Road Economic Belt, which connects China to Central and South Asia and eventually Europe, and the New Maritime Silk Road, which connects China to Southeast Asia, the Gulf states, North Africa, and Europe. Put together, these corridors may be interpreted as twin pillars to the emergence of a vast meta-region, Greater Eurasia, that spans parts of three continents: Asia, Africa and Europe (for more on the concept of Greater Eurasia, see Bordachev [7]). This network would expand the international use of the Chinese currency, the renminbi, while the "Belt and Road" - vast e-commerce market and platform for innovation using cutting-edge technologies - is meant to enhance connectivity by facilitating connectivity and investments.

These two corridors constitute the geographic core of the BRI, but the initiative also has acquired radial reach into other regions; six other economic corridors have been identified linking other countries to the Belt and the Road, and the Chinese government has intensified its overtures to states well outside this perimeter, especially as its rivalry with the United States (including the trade wars started by President Donald Trump) intensify. The March 2019 entry of Italy into the BRI, viewed as many as a snub to Washington, triggered a broader debate about the role of Western states in the initiative. Even further away from China, the effects of the BRI have begun to be felt. A few Latin American states have begun engaging with the BRI but to varying degrees of intensity and formalization, ranging from meetings at the level of head of state to the sending of lower-level envoys to BRI events [8].

The initiative has an incipient governance structure jumpstarted by the Belt and Road Forum for International Cooperation, held on May 14-15 in Beijing with 29 foreign heads of state and government representatives from more than 130 countries and 70 international organizations, including UN Secretary General António Guterres. If a robust governance system emerges out of these processes, the BRI may become a normative power to compete with the UN, Bretton Woods Institutions and OECD. However, the BRI also faces a series of challenges, ranging from the lack of a central coordination mechanism to potential clashes with different political regimes and questions about the financial viability of cross-border projects [9]. There are ongoing debates about the scope and style of China's capacity to steer this process, especially given its domestic challenges and its official foreign policy principle of non-interference in other countries' domestic affairs. Especially since 2017, observers have also voiced growing concern with the amount of debt that may be incurred by participating states, especially in relation to the Chinese banks and other institutions that provide credit for the infrastructure development.

The vision now known as BRI has since served as a central organizing element in the redefinition of China's international insertion. Namely, through the promotion of this contiguous yet multi-continent space, China seeks to consolidate its influence over a spatially defined territory even outside its own national borders. The creation of this meta- 
region (Greater Eurasia) is based on the idea of connectivity, but can be more precisely characterized as a deeply asymmetrical hub-and-spokes model that, far from rendering the nation-state (including the Chinese one) obsolete, remains dominated by national governments even as other actors, such as private sector companies and civil society entities, are pulled into the initiative, namely through the opportunity to engage in major infrastructure development.

Despite China's frayed relations with a number of regional powers in the Greater Eurasian space, a number of other regional powers, including India, Pakistan, Iran, and Russia have become pillars of the emerging new meta-region, whether due to their economic weight within the region or to their ability to influence its politics and security dynamics. Russia's growing rivalry with the United States and its allies intensified through Moscow's 2014 annexation of Crimea and, starting in 2015, its heavy involvement in the Syrian war, and relations were further frayed by accusations of Russian interference in the United States 2016 presidential election. Whereas in the early 2010s, Russia's contestation of the United States had a weak spatial basis, with the BRI it acquires a geopolitical and geoeconomic manifestation that tends to further distance the US from some of its Eurasian partners, especially if the initiative is successfully implementation.

At the same time, the wavering international leadership of the United States, combined with the lack of clear alternatives, has weakened Western-centric global institutions, including the United Nations and components of the Bretton Woods system. While the United States continues to be a major force in world affairs amidst all these changes [3], it has become far more vulnerable to contestation and rivalry from abroad. In addition, uncertainties in Europe, such as the Brexit process and the spread of nationalist populism with a strongly anti-globalist rhetoric, also cast into doubt the role of the West in this multipolarizing world order. At the same time, the weakening and introspection of some rising powers after a period of effervescence - primarily Brazil and South Africa, both members of the BRICS and the India Brazil South Africa (IBSA) Dialogue Forum - reflects the fragility of at least some of the sources of contestation.

At a political level, the BRI's implementation depends not only on the deepening of ties between China and other regional powers in Greater Eurasia, but on the more than 70 countries that are (as of March 2019) officially a part of the initiative. In October 2017, the Chinese Communist Party included the BRI in its constitution, reflecting the degree to which China's leadership is committed to the initiative in the long run. In other states, commitment varies, with popular opposition growing in a number of participant countries, including over issues of transparency and accountability.

Despite the spatial definition of the BRI, we can consider that the initiative in fact operates in three implicit concentric circles. The core circle refers to those states that are formally included in the initiative - as of 2019, over 100 countries had signed up to take part in the initiative. However, the BRI is not constrained to this space. A second concentric circles refers encompasses parts of the world that are not within this space but where the Chinese government has made overtures for cooperation by promoting the idea of inclusion in the BRI. The large number of countries represented at the First Belt and Road Forum reflects this second circle. This includes, for instance, parts of the Western coast of Africa, as some countries in Latin America despite their respective distances from the "core" BRI space. Since 2017, the Chinese government has actively worked to expand this second circle by actively promoting the BRI to states well beyond the BRI geographic area. 
In January 2018, for instance, China invited Latin America and Caribbean countries to join the BRI as part of an agreement to expand economic and political cooperation that already includes not only bilateral ties, but also a broad agreement signed with the Community of Latin American and Caribbean States (CELAC).

A third concentric circle refers to countries that are not directly engaging with the BRI, but which stand to be impacted by its implementation, even if this process is only partial due to the challenges mentioned above. Although there is no straightforward hierarchical relationship between these concentric circles, the density of infrastructure and digital projects within the first suggests that this wil be the area most directly involved and affected. As those states undergo transformation-not only due to greater connectivity, but because many are rethinking key components of their development models in light of the BRI - they will also affect state in the second concentric circle, and so on. Due to this spatial configuration, in general the BRI can be expected to have more immediate and greater impact on states within the first concentric circle.

Within the ripple effect, changing relationships among the first concentric circle of the BRI - which contains some of Brazil's top trade partners, such as South Korea, as well as other important commercial and investment partners, including India, Russia, and the states of Southeast Asia [10] - reshape relations with geographically distant countries, including Brazil. In some areas, trade and investment or even defense partners may find new alternative partnerships that can supply demands currently filled by Brazil, especially in terms of commodities.

The global "ripple effect" of the BRI is due not only to its sheer scope and economic weight, but also due to its potential as a normative platform. Far from creating a straightforward infrastructure corridor, the consolidation of Greater Eurasia around the BRI suggests the formation of a new normative hub. This normative power, however incipient, helps to extend the influence of the BRI far beyond the corridor stretching from Eastern China to Western Europe. Both those who take part in the initiative (and their involvement varies widely, even for those in the core space) and those who remain outside of it are already starting to be affected by the consolidation of the BRI as a political space, and China's overtures to regions outside this immediate vicinity can be understood as being driven at least in part by its deepening rivalry with the United States.

These dynamics indicate that the true scope of the BRI is still being defined and is sometimes taken to mean that the initiative is in fact open to all countries as well as international and regional organizations. China's broad invitation to Latin America and the Caribbean, for instance, remained vague in that few details were divulged about how this linkage would work in practice. Brazil can be thus considered part of the third concentric circle of the BRI, since it has only engaged with the BRI on an ad hoc basis and without any degree of formality.

\section{b) Brazil-China Relations in the BRI Era}

Over the past five years, the study of Brazil-China relations has experienced a boom, especially from the Brazilian side. In addition to an uptick in the number of journal articles, books, policy papers, reports, and theses dedicated to the topic, there is a wave of institutionalization, with dedicated chambers of commerce, think tanks, and new associations of researchers working on Brazil-China ties. This focus is a result of the rapidly 
intensifying and expanding economic bilateral ties between Brazil and China, especially since the 1990s with the expansion of commercial exchanges. However, the research that has emerged during this period has focused rather narrowly on bilateral ties, either analyzing trade and economic relations or concentrating on other areas, such as science and technology, defense cooperation, or cultural ties. It has also been predominantly statecentric, although sociologists and athropologists in particular have begun exploring links and circuits among other actors [11].

Brazilian perspectives on China must be understood in light of the history of these ties. The first official contact involving Brazil and China took place in 1812, when hundreds workers from Macau were brought to Rio de Janeiro, at the request of Dom João, to work on a tea plantation in Rio de Janeiro. However, the Chinese community in Brazil remained small until 1900, when a new and much larger wave of immigrants of China settled in São Paulo, establishing a dynamic community of Chinese migrants and their descendants. Formal relations between Brazil and China started around this same time yet were interrupted by the Chinese Revolution of 1949, to be re-established only in 1974, when the two countries signed a Joint Communiqué in which Brazil recognized the People's Republic of China as "the only legal government of China" and reaffirmed that "Taiwan is an inalienable part of the PRC's territory" [12]. Embassies were then opened in Beijing and Brasília.

Since then, despite the vast geographic distance separating these two countries, they have often drawn on self-identification as developing countries to find common ground. Starting in the 1980s, as China began gradually opening up its economy under the leadership of Deng Xiaoping, the two countries explored niches for cooperation, especially along economic and technology lines. In July 1988, the CBERS program (China-Brazil Earth Resources Satellite) was launched for the construction and launch of satellites for remote sensing systems (since then, five satellites have been launched - in 1999, 2003, 2007, 2013 and 2014). This program represented an early yet significant step towards diversifying Brazil-China ties, and its success showed that cooperation in areas other than trade could also be advanced.

Political ties remained scarce and largely pro forma until the 2000s. Although by 1989 Brazil had transitioned from military to democratic regime, the Chinese government crackdown on protesters demanding greater political space at Tiananmen Square in June 1989 did not have a significant or lasting impact on bilateral relations, which at the time were strongly focused on economic exchanges. There was, nonetheless, a gradual institutionalization of cooperation ties. In 1993, Brazil and China established a Strategic Partnership and, in 2004, the High Level Sino-Brazilian Committee for Coordination and Cooperation (Comissão Sino-Brasileira de Alto Nível de Concertação e Cooperação COSBAN). Since 2010, despite some oscillation in its degree and scope of activities, this body has followed a Joint Plan of Action. Through these frameworks, Brazil-China relations could be expanded along jointly agreed-upon channels and were accorded a higher level of strategic value by leaderships on both sides, as evidenced by a series of official visits by the two countries' heads of state ${ }^{1}$. Ties also began expanding between state-level

${ }^{1}$ From the Brazilian side, there were state visits to China by Presidents Luiz Inácio Lula da Silva (in 2004 and 2009), Dilma Rousseff (2011) and Michel Temer (2017), as well as by Vice-Presidents José Alencar (2006) and Michel Temer (2013). From the Chinese side, Presidents Hu Jintao (2004 and 2010) and 
governments, political bodies, as well as civil society entities such as think tanks, universities, and research centers.

In 2009, China surpassed the United States to become Brazil's top trade partner. The importance of China as an economic partner to Brazil is reflected in the fact that, in 2014, Brazil officially recognized China (which had entered the WTO in 2011) as a market economy even though industrial actors in Brazil feared (and continue to fear) that, when corresponding changes are made to the trade agreements that accompanied this recognition are implemented, new barriers will be created to antidumping measures against Chinese goods [13]. In 2012, when then Prime Minister Wen Jiabao visited Brazil, the strategic partnership was elevated to the status of "Global Strategic Partnership", and a dialogue mechanism was established at ministerial level, along with a Ten-Year Cooperation Plan for the period 2012-2021 [12]. This plan specifies the main areas of bilateral cooperation: science, technology and innovation and spatial cooperation; energy, mining, infrastructure and transport; investments and industrial and financial cooperation; economic-commercial cooperation; and cultural cooperation and exchanges.

China has become the most important market for Brazilian products and, therefore, plays a decisive role in the national trade balance. From January to September 2018, Brazilian exports to China totaled some USD \$ 47 billion, more than double the sales to the United States. According to the Brazilian Ministry of Industry, Foreign Trade and Services, in 2017 trade between the two countries totaled USD \$ 58.49 billion. Brazil's exports to China reached USD \$35.13 billion, with a Brazilian surplus of USD \$11.76 billion. The content of this trade is far from symmetrical, however. China sells a large quantity of industrialized products to Brazil, including electronic products, machinery, tools, textiles. On the other hand, Brazil predominantly sells primary products such as soybeans, iron ore, petroleum. In other words, China's exports to Brazil have much higher added value, and the gap has widened as China invests in innovation and upgrading its services and manufacturing sectors while Brazil fails to diversify its economy, even with a sharp drop in the price of the commodities it exports.

Brazil, however, is among the few countries that have a surplus with China. China, moreover, is essential to Brazil's trade surplus, accounting for one-third of the total in 2017. From the Brazilian perspective, trade benefited from the surge in prices of agricultural commodities and minerals, although most of those have since fallen significantly. With a consumer market of over 1.3 billion people, Chinese demand for Brazilian products is expected to increase, especially as China's population continues to undergo urbanization, improvements in living conditions and rising incomes.

China has also become a significant investor in Brazil, especially after the latter began experiencing economic recession, in 2015. As of 2018, it was ranked $13^{\text {th }}$ among sovereign foreign investors in Brazil. These investments have started to diversify from financial sector (especially through purchase of Brazil-based companies) to joint ventures and greenfield projects [14]. In 2017 alone, China invested \$ 10 billion last year, and the accumulated stock of investments reached $\$ 30$ billion, according to the Chinese Foreign Ministry. Investments by Chinese state-owned enterprises in Brazil have concentrated in the areas of infrastructure, mainly related to energy and transport, as well as in the agricultural sector. Major companies have entered the Brazilian market. For instance, the

Xi Jinping (2014), Vice-Presidents Xi Jinping (2009) and Li Yuanchao (2015), and Prinisters Wen Jiabao (2012) and Li Keqiang (2015) visited Brazil. 
China Three Gorges and State Grid are now highly active in Brazil's energy sector. In 2017, China Three Gorges assumed the concession two large-scale hydroelectric plants (Jupiá and Ilha Solteira) along the Paraná River. Brazilian investments in China, however, face high barriers to entry and lack of familiarity with Chinese institutions, markets, and cultural practices.

The Brazilian economic crisis and a political shift from the left-wing governments of Luiz Lula Inácio da Silva and Dilma Rousseff, both of the Workers Party (Partido dos Trabalhadores, PT) to conservative ones under the Brazilian Democratic Movement Party, PMDB (under Michel Temer) and the far right (under Jair Bolsonaro, since January 2019) caused some changes, at least at the level of discourse. The government of Michel Temer, who assumed the presidency in August 2016 after Dilma Rousseff was impeached, promised to open up new possibilities of foreign direct investment in areas that had long been closed off to non-Brazilian actors, including Chinese companies. These infrastructure concession projects were designed to continue attracting Chinese companies, which have access to relatively cheap capital and often have the implicit or overt backing of the Chinese government, especially in areas considered to be vital to Chinese food, water, and energy security. The government also state it would expand the establishment of joint ventures between Chinese and Brazilian financial institutions. Haitong, a Shanghai investment firm, acquired the Banco do Espírito Santo in Portugal, and then entered Brazil. However, in practice the Temer measures taken by the government were minimal.

In 2018, candidate Jair Bolsonaro ran a successful presidential campaign on a farright campaign that included, among other promises, that of cutting ties with Beijing and recognizing Taiwan. He stated openly, for instance, that "China doesn't want to buy in Brazil - it wants to buy Brazil," and that his government would steer clear of Communist partners. In reaction, China took the unusual step of publishing an op-ed in the China Daily stating that there was "no reason for 'Tropical Trump' to disrupt relations with China" [15]. However, after Bolsonaro assumed the presidency, in January 2019, he changed his tone. By March 2019, he announced he would visit China later in the year, indicating that there would be more continuity than change, and no abrupt disruption as had been announced during the elections.

One of the reasons for this change of mind is that, by 2019, Brazil-China relations had become well institutionalized and had undergone a considerable degree of diversification. In addition, far from being limited to bilateral channels, relations between these two countries had also expanded via a wide variety of multialteral settings. These range from established multilateral organizations, from the United Nations to the Bretton Woods institutions, to newer arrangements, including the BRICS New Development Bank. The 2006 establishment of the BRIC coalition (Brazil, Russia, India, and China), which in 2012 expanded to BRICS with the addition of South Africa, represented a landmark for Brazil-China relations in that, in addition to contesting Western-dominated institutions and norms, the BRICS considerably expanded cooperation channels among themselves, even if in an asymmetrical fashion. Although the BRICS has lost steam and Brazil has scaled back its participation since the end of the Lula presidency, the grouping has maintains an important symbolic weight, and even Brazil's conservative governments have not done away with Brazil's membership. These multilateral channels add weight to the expanded bilateral ties, making it politically and economically almost impossible for Beijing to cut ties with Beijing despite the bravado by far-right groups in Brazil. Finally, the long- 
term impacts of the China-United States trade wars on Brazil remain highly uncertain, but the consolidated cooperation channels mean that US overtures in Latin America meant to pry the region's states away from China are bound to find limited success, even with USfriendly governments such as that of Bolsonaro.

\section{c) Broadening the Lens on Brazil-China Relations}

The heavy concentration on bilateral economic ties within the literature on BrazilChina relations and its heavy focus on economic ties means that few Brazilian scholars have taken into account how China's changing role within its own region - and, more broadly, within Greater Eurasia - affect those ties, as well as political, cultural, scientific and defense links. This gap is important due to at least three reasons. First, the broad structural changes taking place at a global level, namely with the transition towards an asymmetrical multipolar order, have repercussions for every region of the world, even for those actors not located within the epicenters of geopolitical and geoeconomic change. Debates have intensified around the transformation of the world order, including the question of whether the so-called liberal democracy paradigm has reached the point of exhaustion. The illiberal and often erratic foreign policy of the United States under Trump has prompted new questions about its role on the world stage, while the Brexit vote and disagreements within the rest of the European Union have also cast into doubt the political coherence and leadership capacity of the West.

Second, these structural changes are accompanied and possibly partly propelled by political movements, such as nationalism and populism, that have reshaped domestic politics and foreign policy alike in states as geographically distant as Brazil, Turkey and the Philippines. In Latin America, in particular, some of these governments - including that of Bolsonaro - have weakened the discourse of South-South cooperation that had occupied center stage in foreign policymaking during the 2000s, concentrating heavily on relations with Western powers, especially along the trade and investment front. In March 2019, for instance, after meeting with Trump in Washington, Bolsonaro cemented a new alliance with the United States that includes not only expanded economic ties (especially via concessions by Brazil) in exchange for a vague promise of US support for Brazil's bid to join the OECD, but also an invitation by Trump for Brazil to join the North Atlantic Treaty Organization (NATO) [16].

Third, a broader perspective on Brazil-China relations is needed because regional changes have taken place (both in Eurasia and in Latin America) that generate new competing interests, and political alignments, and that change the relative salience of certain international organizations. In Latin America, the swing from left-inspired governments to conservative ones has altered the landscape of regionalism, for instance exacerbating the political paralysis that had already taken root in UNASUR - in effect, replacing it with the right-leaning PROSUL - and casting doubts about the robustness of Mercosur. In Eurasia, the BRI is emerging within a landscape already populated by regional organizations, from the Shanghai Organization for Cooperation (SCO) to the Association of Southeast Asian Nations (ASEAN), among others, and there too the landscape of regionalism has been shifting.

Thus, far from existing within a vacuum, Brazil-China relations take place against the backdrop of, and thus are also shaped by, these broader geopolitical, geoeconomic, and 
political tectonic shifts at varying scales, from the global and the regional to the national and the local. The next section of this paper this considers some of the key ramifications of the BRI for Brazil-China ties across three areas: economic, strategic, and political relations.

\section{BRI Impact on Brazil-China Relations}

\section{a) Economic Ramifications of the BRI for Brazil-China Relations}

The economic impact of the BRI refers to its effects in areas such as international trade, cross-border investment, allocation of economic activity and patterns of inclusive and sustainable growth in BRI countries. It is hard to understate the economic weight of the BRI, however one defines the initiative. Taking into account only the "core states" corresponding to those within the first concentric circle - the bloc represents over $30 \%$ global GDP, $62 \%$ of the world's population, and $75 \%$ of known energy reserves. This scale has promted comparisons or allusions to major economic transformation programmes, such as the Marshall Plan. The Marshall Plan was implemented after World War II so as to rebuild Western Europe entailing US \$ 44.3 billion in grants between 1945 and 1953; it helped to nudge the United States out of its pre-war isolationist stance and to consolidate its economic and political dominance at a global level. In this comparison, the BRI is China's way of using aid and cooperation to expand its power-not just economic, but also political and strategic-within a vast geographic corridor. Beijing has insisted that this comparison is misguided because officially it promotes the BRI as a purely economic initiative [17], but there is growing concensus that the vision is also driven by Chinese political considerations, defense interests, and other factors.

More specifically, the BRI has been promoted as a truly transformative vision for states that become closely involved, especially through investments in infrastructure and connectivity, including within the digital sphere. Yet the impact of the BRI cannot be measured with reference to single states alone; there is a regional effect as well, for instance through transnational projects, cooperation ties, and policy reforms.

Part of this economic potential comes from the fact that the BRI is anchored, economically, in the creation of multimodal transport infrastructure in a region that has lower levels of such investments when compared to other regions. A recent study by Rand concluded that, among the economic growth related results of the initiative, the region will experience facilitated trade expansion, expanded foreign direct investment, accelerated industrialization, greater regional integration, and intensifying economic growth in the area covered by the infrastructure projects [18]. The report concludes that the BRI will cause total trade volumes to increase not only in the BRI region, but also in those states outside the initiative. The planned transport infrastructure is thus expected to significantly reduce the cost of transporting goods and people across borders, making trade more efficient and expanding the reach of commercial flows across the BRI. Critics and skeptics note, however, that the growth generated through the BRI may be accompanied by new forms of inequality, for unstance the formation of new pockets of prosperity along new islands of social exclusion [19].

Understanding the costs and benefits of participation is thus essential to the negotiation of membership terms. If, on the one hand, the BRI is likely to disrupt economic 
and other dynamics, it also opens up new windows. Through the BRI, new opportunities are arising in construction, energy, and infrastructure sectors - all areas in which Brazilian companies have extensive experience. In addition, the BRI is already fomenting a number of large-scale infrastructure development projects in other parts of the world, including the Nairobi to Mombasa railway. The BRI could therefore become another channel through which Brazil can deepen its economic ties to China and to Greater Eurasia more broadly. Key considerations, however, will include the degree to which doing so would mean incurring high-risk debt, as well as the political ramifications of deepening ties to what is at hard a Chinese project, especially at a time when China-US relations are frayed.

\section{b) Strategic Ramifications of the BRI for Brazil-China Relations}

In creating a new geopolitical and geoeconomic center of gravity based in Greater Eurasia, the BRI further erodes United States hegemony and reconfigures, both politically and spatially, the dynamics of power at regional and global levels. Brazil's relationship with China has traditionally followed bilateral channels, whether economic, military, or otherwise. Over the past five years, this bilateral portfolio has expanded from narrow economic cooperation along trade and investment to a broader range of military and defense ties, driven in part by China's increasingly strong and internationalized military institutions and the now-global reach of the People's Liberation Army Navy, PLAN (Chinese warships now regularly dock in Brazilian ports). Brazil and China signed a cooperation agreement on defense issues in 2011, and since then the two countries have worked to diversify these ties. In 2014, Brazil and China signed an agreement to cooperate on the Amazonian Protection System, which uses remote sensing, telecommunications and information technology to assure the defense of Brazil's Amazon region [20]. The following year, Brazil and China began working towards intensifying officer exchanges in training and exercises, including related to peacekeeping, in the two countries' military academies [21]. Since then, however, there have been no major leaps in the bilateral defense cooperation, although the Brazilian Army has expressed interest in deepening cooperation on defense technologies [22].

Brazil and China have also interacted on strategic issues via multilateral fora, whether established institutions such as the UN, the World Trade Organization (WTO) and the Bretton Woods institutions, or via ad hoc coalitions such as the BRICS and the BASIC configuration (a loose political alliance consisting of Brazil, South Africa, India, and China-formed in 2009 in an effort to act jointly at the Copenhagen climate summit). The BRI, however, has a spatial logic that these multilateral platforms lack, even if this logic is expansive to the point of sometimes being vague. The BRI, morevoer, has already begun to interact, overlap with and juxtapose onto a number of regional organizations. From ASEAN to the European Union, from the Shanghai Cooperation Organization to the Secretariat of the Pacific Community (SPC), the BRI membership overlaps with those of several regional organizations spanning dozens of countries. In addition, the "core" BRI space coincides with some of the free trade areas under negotiation, from the (now-defunct) proposed Trans-Pacific Partnership (TPP), to the Regional Comprehensive Economic Partnership (RCEP). Although the impact of BRI on these organizations and proposals is still unclear, there is little doubt that the realignment among the member states that make 
up these arrangements will alter not only the economic landscape but also the political and military dynamics of Greater Eurasia, and beyond.

The involvement of major financial institutions, from the AIIB to the World Bank, in the BRI is also of strategic relevance to Brazil. The World Bank Group has committed some US $\$ 80$ billion for infrastructure in the BRI countries, as well as technical and advisory services [19]. Some of the bank's practices have reportedly shifted due to the competition arising from these new institutions. In this sense, the BRI has thus already begun to influence the norms and practices of major global and regional institutions in which Brazil takes part.

\section{c) Political Ramifications of the BRI for Brazil-China Relations}

Over the past two decades, bilateral Brazil-China relations have included visits by heads of state (in both directions), as well as meetings at ministerial and other levels, but ties have also expanded between government divisions and political parties. Although officially China prefers to focus on economic factors in its negotiations, it has proven increasingly willing to comment directly on and even pressure other states' political affairs, especially when Chinese leaders feel that the One China Policy is threatened. The November 2018 "warning" Jair Bolsonaro signaled in no unclear terms Beijing's strong displeasure with anti-Beijing statements by the candidate whom the China Daily referred to as the "Tropical Trump" [15]. The editorial was interpreted by many in Brazil as a threat meant to put the Bolsonaro government on the track of continuity with Beijing ties. While this strong statement took place within the confines of bilateral relations, China's increasing political involvement with BRI countries, which spills over from the economic to the political, may have emboldened it to address in more direct ways the domestic political dynamics in other states, including those in Latin America. The BRI may therefore serve as a testing ground for what some have referred to as Beijing's growing (if very incipient) willingness to intervene politically in other states' internal affairs.

Such willingness will be especially consequential if China's singular brand of authoritarianism spreads via the BRI. One example of how this may occur is through Chinese exports of new technologies for communications that are bundled with social surveillance mechanisms. China has been pioneering the use of facila recognition in state surveillance and exporting this package to other states, including several within the BRI. If the emerging Digital BRI remains dominated by China, it is possible that non-democratic norms will spread.

By and large, however, China has proven reluctant to engage in Latin American politics even when there are specific demands for such engagement, preferring instead to frame negotiations in narrowly economic terms except when referring vaguely to ties of friendship between the states. At the same time, some Latin American states' growing indebtedness to China may grant Beijing political as well as economic leverage, particularly given the region's proneness to cycles of crisis and uneven growth. The intensifying crisis in and Venezuela, with rival camps emerging around the contested leaderships of Nicolás Maduro and Juan Guaidó, reflects the strong but sometimes ambiguous position of China even in cases where it still holds the purse strings. In that particular crisis, Brazil and China have found themselves on opposite sides.

The main political consequence of BRI for Brazil-China relations, however, is that, to a certain extent, the BRI reorders Beijing's foreign policy priorities, creating (from a Latin 
American perspective) new interests that may potentially compete with its Latin American interests. Although Beijing has signaled that, even as it pursues the implementation of the BRI, it also continues to place strategic importance on Latin America - not least due to the region's abundance in food, energy and water resources - the consolidation of a China-led Greater Eurasia entails massive political shifts that Brazil has been slow to mintor, much less to engage in. While other Latin American countries sent heads of state to the Silk Road Forum, for instance, Brazil sent a sub-ministerial delegation.

\section{Conclusion}

Although the BRI is increasingly promoted by China as an inclusive, even global initiative based on a loose idea of connectivity, it is far from a homogeneous space, and China's leadership suggests new or reinforced asymmetries within this vast space. In addition, defining this space has become an increasingly complex task, as there are degrees of involvement by states. As a result of these variations, the BRI's direct and indirect impact around the world is also bound to vary immensely. In the case of Brazil-China relations, bilateral ties historically have focused heavily on economic cooperation, primarily via trade and investment, even as the two countries pursue greater interaction through a wider variety of bilateral frameworks and multilateral from the UN and the World Bank to the G20 and the BRICS.

The BRI has serious consequences for Brazil-China relations first because the initiative has begun to reconfigure trade and especially investment flows, concentrating them within Greater Eurasia. From a strategic standpoint, the emergence of a new geopolitical and geoeconomic global hub of power affects Brazil's position in the world order more broadly, possibly casting Brazil (if it fails to engage productively with the initiative) into a reinforced periphery - one now constructed vis-à-vis the Eurasian center rather than the old European core. In addition, Brazil's defense ties with China, which have slowly acquired greater weight in recent years but in a highly uneven fashion, may be affected not only by China's changing role and interests in Greater Eurasia, but also by Beijing's sharpening rivalry with the United States in Latin America.

Politically, the initiative also reshape alignments in ways that are only beginning to emerge, including intensifying debates within Western Europe about whether individual member states or the entire European Union should formally join the BRI. The authoritarian nature of the Chiense regime and its central place in the promotion, financing and implementation of the BRI - not to mention its emerging governance - also raises question about the values and principles that will become associated with the initiative. With respect to the political sphere, China has become somewhat more willing to speak out on the internal affairs of other states, particularly when its leadership feels that the One China policy has come under threat. Since Latin America is the region of the world with the largest number of countries that maintain ties to Taiwan as well as a place where some countries have switched allegiances, the Chinese government is particularly attentive and sensitive to shifts in foreign policy towards China, as illustrated by its swift response to Bolsonaro's foreign policy statements during the 2018 presidential campaign.

The BRI is somewhere between a vision and a project, and it remains a moving target - consequently, so are Brazil-China relations. Further research on this topic would benefit from Chinese perspectives on how the BRI relates to Latin America and the Carib- 
bean, as well as Brazil more specifically. In Brazil, more research and debate are needed on the specific consequences of joining the BRI under the terms that are emerging. Finally, a comparative perspective including other Latin American and Caribbean countries would help to shed light on the differential impact of the BRI across the region as the initiative gets implemented.

\section{References}

1. Beccard, D. (2011), "O que esperar das relações Brasil-China?" [What to expect from Brazil-China relations?], Revista de Sociologia Política, vol. 19, pp. 31-44.

2. Mearsheimer, J. (2013), "Structural Realism", in Dunne, T., Kurki, M. and Smith, S. (eds), International Relations Theories: Discipline and Diversity, Oxford University Press, Oxford, UK, pp. 77-93.

3. Acharya, A. (2018), The End of the American World Order, John Wiley \& Sons, Hoboken, USA.

4. Cooper, A.F. and Pouliot, V. (2015), "How much is global governance changing? The G20 as international practice", Cooperation and Conflict, vol. 50, no. 3, pp. 334-350.

5. Wade, R.H. (2011), "Emerging World Order? From Multipolarity to Multilateralism in the G20, the World Bank, and the IMF", Politics \& Society, vol. 39, no. 3, pp. 347-378.

6. Zhou, Z. Y. (2017), Achieving Food Security in China: The Challenges Ahead, Routledge, London, UK.

7. Bordachev, T. (2018), "Greater Eurasia and Russian Foreign Policy Priorities", Asian Politics \& Policy, vol. 10, no. 4, pp. 597-613.

8. Abdenur, A.E. and González, A. (2018), “Trans-Regional Cooperation in a Multipolar World: How is the Belt and Road Initiative Relevant to Latin America?" London School of Economics Global South Unit Working Paper 1, available at: http://www.lse.ac.uk/international-relations/assets/documents/globalsouth-unit/Working-Paper-No.-1.-2018-Adriana-Abdenur-and-Ariel-Gonz \%C3 \%A1lez.pdf (accessed: 30.03.2019).

9. Huang, Y. (2016), “Understanding China's Belt \& Road Initiative: Motivation, framework and assessment", China Economic Review, vol. 40, pp. 314-321.

10. The Observatory of Economic Complexity - OEC. Brazil, available at: https://atlas.media.mit.edu/en/ profile/country/bra/ (accessed: 30.03.2019).

11. Pinheiro-Machado, R. (2018), Counterfeit Itineraries in the Global South: The human consequences of piracy in China and Brazil, 2017, Routledge, London, UK.

12. Ministério das Relações Exteriores. República Popular da China [Ministery of Internatnational Relations. People's Republic of China] (2019), available at: http://www.itamaraty.gov.br/pt-BR/fichapais/4926-republica-popular-da-china (accessed: 30.03.2019).

13. Rabih, A.N. (2015), "Consequências do reconhecimento da China como economia de Mercado" [Consequences of the recognition of China as a market economy], ITCSD, 18 March, available at: https:// www.ictsd.org/bridges-news/pontes/news/consequ \%C3\%AAncias-do-reconhecimento-da-china-comoeconomia-de-mercado (accessed: 30.03.2019).

14. Abdenur, A. E. (2017), "Skirting or Courting Controversy? Chinese FDI in Latin American Extractive Industries", International Development Policy, vol. 9, pp. 174-198.

15. "No reason for 'Tropical Trump' to disrupt relations with China" (2018), China Daily, October 29, available at: http://www.chinadaily.com.cn/a/201810/29/WS5bd702e9a310eff303285424.html (accessed: 30.03.2019).

16. Bentes, P. M. (2019), "Bolsonaro tomou um golaço político da administração Trump” [Bolsonaro suffered a political goal from the Trump administration], Folha de São Paulo, March 24, available at: https:// www1.folha.uol.com.br/mercado/2019/03/bolsonaro-tomou-um-golaco-politico-da-administracaotrump.shtml (accessed: 30.03.2019).

17. "Beijing insists BRI is no Marshall Plan" (2018), Financial Times, September 25, available at: https:// www.ft.com/content/48f21df8-9c9b-11e8-88de-49c908b1f264 (accessed: 30.03.2019).

18. "China Belt and Road Initiative: Measuring the impact of improving transport connectivity on international trade" (2018), Rand Corporation, available at: https://www.rand.org/randeurope/research/ projects/china-belt-and-road-initiative.html (accessed: 30.03.2019).

19. "Belt and Road Initiative" (2018), World Bank, March 29, available at: https://www.worldbank.org/ en/topic/regional-integration/brief/belt-and-road-initiative (accessed: 30.03.2019).

20. Ministério da Defensa. Formado acordo entre Brasil e China no âmbito do Sistema de Proteção da Amazônia [Ministery of Defense. Agreement signed between Brazil and China on the Amazon Protection 
System] (2014), available at: https://www.defesa.gov.br/index.php/noticias/13189-firmado-acordo-entrebrasil-e-china-no-ambito-do-sistema-de-protecao-da-amazonia (accessed: 30.03.2019).

21. Ministério da Defensa. Brasil e China vão intensificar o intercâmbio entre militares [Ministery of Defense. Brazil and China set to deepen military exchanges] (2015), available at: https://www.defesa.gov.br/ noticias/15534-brasil-e-china-vao-intensificar-o-intercambio-entre-militares (accessed: 30.03.2019).

22. "Exército Brasileiro busca maior intercâmbio com a China na area de Ciência e Tecnologia de Defesa" [Brazilian Army seeks greater exchange with China on Military Science and Technology] (2018), DefesaTV, December 3, available at: https://www.defesa.tv.br/exercito-brasileiro-busca-maior-intercambiocom-a-china-na-area-de-ciencia-e-tecnologia-de-defesa/ (accessed: 30.03.2019).

Received: November 15, 2018

Accepted: February 14, 2019

Author's information:

Adriana Erthal Abdenur — PhD, coordinator; abdenur@post.harvard.edu 